DOI 10.18551/rjoas.2021-11.28

\title{
THE EFFECT OF NANOTECHNOLOGY MULTIPLE FERTILIZERS ON THE GROWTH AND YIELD OF THREE ONION VARIETIES GROWN FROM TRUE SHALOT SEED
}

\author{
Kartina A.M. ${ }^{1,2 *}$, Tubagus F.A. ${ }^{2}$, Zahratul M. ${ }^{1,2}$ \\ ${ }^{1}$ Departement of Agroecotechnology, Faculty of Agriculture, Sultan Ageng Tirtayasa \\ University, Indonesia \\ ${ }^{2}$ Agricultural Science Program, Graduate School, Sultan Ageng Tirtayasa University, \\ Indonesia \\ *E-mail: kartina plg@untirta.ac.id
}

\begin{abstract}
Shallots are generally propagated vegetatively by using tubers as planting material. The disadvantages of the onion cultivation method using bulbs are that the bulbs are expensive, have higher transportation costs, can transmit disease to the next generation, and have a short shelf life. This resulted in a significant decrease in onion production. One alternative way to overcome the shortage of planting material to increase the production and quality of shallots is to develop shallot planting material from seeds. This research was aimed to know the effect of different concentration of compound fertilizer with nanotechnology to the growth and yield of three shallot varieties (Allium ascalonicum I.) from seed (true shallot seed) in Banten province dry land. The research used a split plot design, with two factors as treatment and three replications. The main plot was the concentration of compound fertilizer with nanotechnology (k) which consisted of four levels: without nanotechnology fertilizer, $2.5 \mathrm{ml} / /, 5.0 \mathrm{ml} / \mathrm{l}$, and $7.5 \mathrm{ml} / \mathrm{l}$ nanotechnology fertilizer. The subplot was varieties which consisted of three levels: Maserati, Lokananta and Sanren varieties. Results showed that the application of nanotechnology fertilizers with a concentration of 5.0 $\mathrm{ml} / \mathrm{l}$ gave the best results to plant height parameters of 3 Weeks After Planting (WAP) ( 25.39 $\mathrm{cm}$ ), number of leaves 4 WAP (8.60 strands) and 5 WAP (11.84 strands), number of bulbs (1.88 bulbs) and wet weight of bulbs per clump (39.29 g). The Sanren variety gave the best growth and yield at plant height parameters of 2 WAP $(20.77 \mathrm{~cm}), 3$ WAP $(26.07 \mathrm{~cm}), 4$ WAP $(32.18 \mathrm{~cm})$, and 5 WAP $(41.12 \mathrm{~cm})$, the number of leaves 2 WAP $(2.77$ strands), 3 WAP (5.88 Stands), 4 WAP (9.13 strands), number of bulbs each plant (2.07 bulbs) and wet weight per clump $(40.84 \mathrm{~g})$. There was no interaction between treatment of nanotechnology compound fertilizers concentration and varieties to all observed parameters.
\end{abstract}

\section{KEY WORDS}

Nanotechnology, fertilizer, onion varieties, true shallot seed.

Onion (Allium ascalonicum L.) is a strategic commodity and has high economic value and cannot be substituted to other commodities. Today Shallots are included in the main food commodity group, because their availability and price greatly affect inflation and the national economy in Indonesia. Onion production is uneven throughout the year, where production decreases in the rainy season which causes high prices and excessive production in the dry season causes prices to fall. This is because farmers' habits in cultivating depend on the season, farmers are reluctant to plant in the dry season, resulting in reduced production in the rainy season, so it is hoped that farmers can do farming in the dry season with a cropping pattern off season (Directorate of Horticulture, 2018).

The productivity of shallots in Indonesia decreased from 2015 to 2019 respectively by 10.06 tons/ha, 9.67 tons/ha, 9.31 tons/ha, 9.59 tons/ha and 9.93 tons/ha. The productivity is still far below its production potential, which is above 20 tons/ha (Ministry of Agriculture, 2020). The low productivity of shallots in Indonesia compared to its production potential is influenced by several factors, including decreased soil fertility, changes in microclimate, high attack of plant pests, and seed quality (Sudaryono, 2017). Seed quality is the basis of every crop production, in this case good preservation is very important to get optimal results. Seed 
quality is also influenced by seed production conditions, cultivars, storage conditions, and postharvest maintenance. During storage, seed viability and vigor are influenced by several factors, including genetic factors, biotic moisture content (micro flowers), humidity, relative temperature, and activity of organisms (diseases, fungi, insects, and rodents) (Selvi and Saraswathy, 2017).

Shallots are generally propagated vegetatively by using tubers as planting material. The seedling that are widely used by farmers are seedling that come from the previous harvest (consumption tubers), are not superior varieties and do not adapt to certain locations. The use of previously harvested shallot bulbs (consumption tubers) as planting material (vegetative propagation) has been going on for a long time. The use of consumption tubers for a long time and continuously resulted in a decrease in the yield of shallots, both quantitatively and qualitatively. The decrease in yield is thought to be due to low seedling quality (Wulandari et al., 2014). The disadvantages of the onion cultivation method using bulbs are that the bulbs are expensive, have higher transportation costs, can transmit disease to the next generation, and have a short shelf life. This resulted in a significant decrease in shallot production (Tabor, 2018).

One alternative to overcome the shortage of planting material to increase the production and quality of shallots is to develop shallot planting material from seeds known as TSS (True Shallot Seed) (Pangestuti and Sulistyaningsih, 2011). Some of the advantages of using TSS are that it increases the yield of shallot bulbs up to two times compared to the use of bulb seedlings (production 26 tons/ha), free of disease and viruses, cheaper (requires less TSS (2-3 kg/ha) at a low price of Rp. $1,200,000 / \mathrm{kg}$ compared to seed tubers $( \pm 1-1,2$ tons $/ \mathrm{ha})$ at a price of $R p 15,000,000-25,000,000)$, transportation is easier, and shelf life is longer than tubers (Balitsa, 2015).

Efforts to increase the productivity of shallots cannot be separated from the role of fertilizer as soil fertilizer. What may not have been achieved well is the increase in the efficiency of fertilizer use which needs to be improved because one of the inhibiting factors for plant production is nutrients (Jamilah and Novia, 2016). Nanotechnology fertilizers have the potential to increase the efficiency of using fertilizers, pesticides, agricultural tools and machinery, and also seeds, through the development of high productivity varieties that are resistant to pests and disease (Ariningsih, 2016). The use of nanotechnology in fertilizers will allow the release of nutrients contained in fertilizers to be controlled. In nanofertilizers, nutrients can be in the form of nanomaterial encapsulation, coating with a thin protective layer or released in the form of an emulsion from nanoparticles (Yanuar et al, 2014).

\section{MATERIALS AND METHODS OF RESEARCH}

This research was conducted in the Integrated Agricultural System (Sitandu) area, Curug district Serang city, Banten province from July to September 2021. The experimental design used was a split plot design, with two factors and three replications. The main plot was the concentration of compound fertilizer with nano $(k)$ technology which consists of four levels: without nanotechnology fertilizer, $2.5 \mathrm{ml} / \mathrm{l}, 5.0 \mathrm{ml} / \mathrm{l}$, and $7.5 \mathrm{ml} / \mathrm{l}$ nanotechnology fertilizer. The sub-plots were three varieties of shallots $(\mathrm{v})$ consisted of Maserati, Lokananta and Sanren varieties. Goat manure 20 t/ha along with 0.1 t/ha N, 0.2 t/ha SP-36 and 0.15 t/ha KCL were applied before planting as the basic fertilizer. Furthermore, NPK fertilizer (15:15:15) was given twice at the age of 20 days after planting (DAP) and 30 DAP, each half of the predetermined dosage. Plant maintenance such as watering, weeding, and controlling pests and diseases is adjusted to the conditions of the plants in the field. The parameters observed consisted of growth components (height plants and number of leaves per clump), yield component (number of tubers and wet tuber weight per clump).

\section{RESULTS AND DISCUSSION}

The average increase in plant height for each treatment for a given concentration can be seen in Figure 1. 


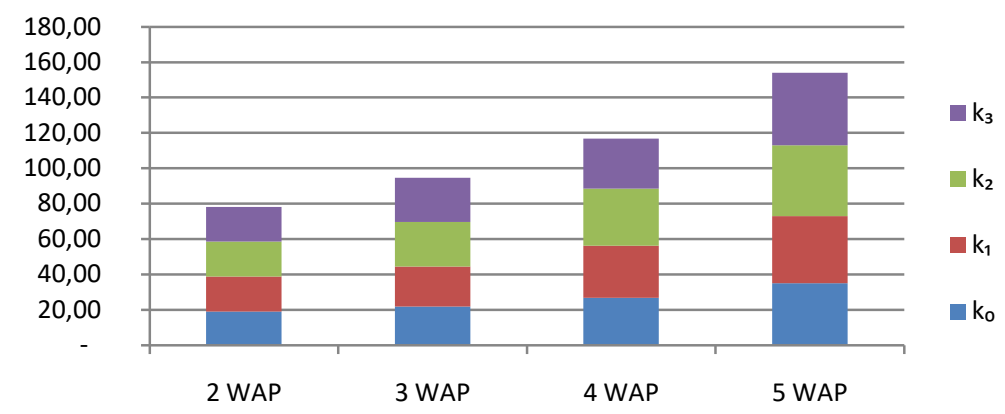

Figure 1 - Increase in onion plant height

Based on Figure 1, the average increase in plant height shows an increase with increasing plant age. The application of nanotechnology fertilizer gave the best response at $5.0 \mathrm{ml} / \mathrm{l}(\mathrm{k} 2)$ at $3 \mathrm{MST}$. The results of the ANOVA test for the responses of three varieties to differences in the concentration of nanotechnology fertilizers can be seen in table 1 .

Based on Table 1, it can be seen that the treatment of three varieties gave a very significant effect on the parameters of plant height aged 2-5 weeks after planting (WAP), with the treatment response of the Sanren variety (v3) shows the highest average plant height, $41.12 \mathrm{~cm}$. Maserati Variety ( $\mathrm{v} 1$ ) has the lowest plant height when compared to other varieties. This is in accordance with the results of Saidah, et al., (2018) which states that the Sanren variety produces the highest value on plant height parameters compared to other varieties. Furthermore, Sumarni et al. (2012) stated that different genetic trait factors can produce different plant heights due to different varieties; this is in accordance with Putri's opinion (2021) stating that plant height is one of the plant growth variables that can be observed as a differentiator for each variety. In general, plant height is also influenced and inherited genetically.

The concentration level treatment of compound fertilizer with nanotechnology gave a significant effect on plant height parameters at 3 WAP, with a concentration treatment response of $5.0 \mathrm{ml} / \mathrm{l}(\mathrm{k} 2)$ shows the highest average plant height, which is $25.39 \mathrm{~cm}$. The treatment of the concentration level of nanotech fertilizer on plant height at the beginning of onion plant growth (2 WAP) had no significant effect because at the age of 2 WAP the plants had not been treated with nanotech compound fertilizer so it was suspected that to meet the nutrient needs of the plant, they still used basic fertilizer given to metabolism. After the age of 15 DAP, the plants were treated with nanotechnology fertilizer so that at the age of 3 WAP the plants had different plant height responses.

Table 1 - The average of plant height $(\mathrm{cm})$ of three varieties of shallot from seed (TSS) on differences in the concentration of nanotech compound fertilizers

\begin{tabular}{|c|c|c|c|c|c|c|}
\hline \multirow{2}{*}{ Age } & \multirow{2}{*}{ Varieties } & \multicolumn{4}{|c|}{ Concentrate of Fertillizer $(\mathrm{ml} / \mathrm{l})$} & \multirow{2}{*}{ Average } \\
\hline & & $\mathrm{k}_{0}$ (control) & $\mathrm{k}_{1}(2,5 \mathrm{ml} / \mathrm{l})$ & $\mathrm{k}_{2}(5,0 \mathrm{ml} / \mathrm{l})$ & $\mathrm{k}_{3}(7,5 \mathrm{ml} / \mathrm{l})$ & \\
\hline \multirow{3}{*}{2 WAP } & $\mathrm{v}_{1}=$ Maserati & 18,77 & 19,92 & 20,61 & 19,39 & $19,67 b$ \\
\hline & $\mathrm{v}_{2}=$ Lokananta & 18,32 & 18,40 & 18,25 & 18,32 & $18,32 \mathrm{a}$ \\
\hline & $\mathrm{v}_{3}=$ Sanren & 19,90 & 20,92 & 20,92 & 20,77 & $20,63 \mathrm{~b}$ \\
\hline \multirow{4}{*}{3 WAP } & Average & 19,00 & 19,75 & 19,93 & 19,49 & \\
\hline & $\mathrm{v}_{1}=$ Maserati & 20,35 & 22,12 & 22,92 & 24,51 & $22,48 \mathrm{a}$ \\
\hline & $\mathrm{v}_{2}=$ Lokananta & 21,73 & 22,06 & 25,19 & 23,87 & $23,21 \mathrm{a}$ \\
\hline & $\mathrm{v}_{3}=$ Sanren & 23,68 & 23,24 & 28,05 & 26,07 & $25,26 \mathrm{~b}$ \\
\hline \multirow{5}{*}{4 WAP } & Average & $21,92 \mathrm{a}$ & $22,47 \mathrm{a}$ & $25,39 \mathrm{~b}$ & $24,82 \mathrm{~b}$ & \\
\hline & $\mathrm{v}_{1}=$ Maserati & 26,03 & 25,83 & 27,77 & 25,49 & $26,28 \mathrm{a}$ \\
\hline & $\mathrm{v}_{2}=$ Lokananta & 26,11 & 29,27 & 31,46 & 30,02 & $29,22 b$ \\
\hline & $\mathrm{v}_{3}=$ Sanren & 28,54 & 32,78 & 37,55 & 29,84 & $32,18 \mathrm{c}$ \\
\hline & Average & 26,89 & 29,29 & 32,26 & 28,45 & \\
\hline \multirow{4}{*}{5 WAP } & $\mathrm{v}_{1}=$ Maserati & 32,95 & 33,67 & 37,69 & 39,86 & $36,04 \mathrm{a}$ \\
\hline & $\mathrm{v}_{2}=$ Lokananta & 34,83 & 39,66 & 37,49 & 41,46 & $38,36 \mathrm{~b}$ \\
\hline & $\mathrm{v}_{3}=$ Sanren & 37,52 & 40,54 & 44,49 & 41,94 & $41,12 \mathrm{c}$ \\
\hline & Average & 35,10 & 37,96 & 39,89 & 41,09 & \\
\hline
\end{tabular}

Note: The numbers followed by the same lowercase letters in rows and columns showed no significant difference in the DMRT test at the 5\% level. 
The nanotechnology fertilizer treatment showed a higher mean value than the control treatment (without the application of nanotech fertilizer), with an $\mathrm{N}$ content of $5.24 \%$ supported by nanoscale particle size, giving a better impact on the vegetative growth of shallot plants from seed ( TSS), the same result was also reported by Nur'aeni (2020) that application of compound fertilizer with nanotechnology concentration of $5.0 \mathrm{ml} / \mathrm{l}$ gave the best growth and yield on plant height parameters, number of leaves and weight of tubers without roots and leaves per clump. This is in accordance with the opinion of Fageria and Baligar (2005) that the application of fertilizer to plants with sufficient nitrogen levels will accelerate the growth and development of plant vegetative organs. At four WAP, plant height growth increased with increasing concentration of fertilizer applied and then decreased when the concentration was increased. Giving too high concentration of fertilizer can inhibit plant growth. This is also in line with Nuryani's et al. opinion (2019) that fertilizer application must be carried out correctly and according to the recommended concentration, because excessive fertilizer application will cause poisoning to plants. Plant production was not optimal can be caused by the application process of fertilization that was not appropriate and in accordance with the concentration.

The results of the ANOVA test showed that the shallot variety (v) treatment showed a significant effect at the age of 2 WAP and a very significant effect at the age of 3 WAP - 5 MST. The number of leaves in the treatment of different concentrations of compound fertilizer with nano $(k)$ technology has a significant effect on age 4 MST - 5 MST, and the interaction between the two had no significant effect. Observational data can be seen in Table 2.

Based on Table 2 it can be seen that the treatment of the three varieties had a very significant effect on the number of leaves per clump, with the response of the treatment of the Sanren variety (v3) showed the highest average of 12.80 strands per clump. The Sanren variety tends to had more leaves and tubers, but the diameter of the tubers produced is smaller than the Lokananta variety.

The relationship between the number of leaves and the number of tubers is positively correlated, It's showed that the higher the number of leaves per clump, the higher the number of tubers per clump. but both were negatively correlated with tuber diameter per clump, this is in line with the opinion of Wati and Sobir

(2018) Sanren variety had higher values of leaf length, pseudo stem diameter, leaf diameter, and number of leaves per pseudo stem. Continued by Saidahet.al (2019) Shallots of the Sanren variety have taller plants and more leaves. It also was in accordance with the description of the Sanren variety, which has taller plants and more leaves than the Lokananta and Maserati varieties.

The Sanren variety was able to adapt well to the environment when compared to the Lokananta and Maserati varieties. It was in accordance with the opinion of Nurjanani and Djufry (2018) that different shallots varieties may differ in terms of adaptation when grown in the same planting site. The influence of varieties could significantly affect differences in plant growth and leaf development. Various factors that could influence include the type and variety of plants. According to Mehran et al. (2016) that the gene potential of a plant would be maximized if it was supported by environmental factors. The more the number of leaves, the more places for photosynthesis to occur so that the photosynthate produced increases. Photosynthate produced would be used by plants to: (1) as an ingredient in plant growth, (2) allocated to the "sink" part of the plant, (3) and stored as food reserves (Pikukuh et.al, 2015).

Different plant varieties had different abilities in growth and leaf formation, plant height, number of leaves, number of tillers, number of cloves, age of harvest, fresh weight and dry weight of tubers per clump as well as shallot production. There were quite a lot of varieties of shallots that were cultivated in Indonesia. Some of the characteristics that can distinguish between these varieties include shape, size, color, elasticity and aroma of tubers, plant age and resistance to disease (Jumini. 2011). Varieties Sanren had the highest plant height and number of leaves. It was in accordance with the opinion of Simatupang (2019) that the number of shallots is not influenced by population but is influenced by shallot varieties.

The treatment of different concentrations of compound fertilizer with nanotechnology significantly affected the number of leaves per clump at the age of 4 WAP and 5 WAP, with a 
concentration treatment response of $5.0 \mathrm{ml} / \mathrm{l}(\mathrm{k} 2)$ shows the highest average number of leaves, it was suspected that the application of fertilizer concentration of $5.0 \mathrm{ml} / \mathrm{l}$ is the optimal amount for plants to absorb nutrients, this is in accordance with Mujahid's opinion et al. (2017) that the application of nanotechnology fertilizers with different doses causes the production of different number of leaves and with the right frequency will accelerate the rate of leaf formation.

Table 2 - The average number of leaves (strands) of three varieties of shallot from seed (TSS) to differences in the concentration of compound fertilizers with nanotechnology

\begin{tabular}{|c|c|c|c|c|c|c|}
\hline \multirow{2}{*}{ Age } & \multirow{2}{*}{ Varieties } & \multicolumn{4}{|c|}{ Fertilizer Concentration $(\mathrm{ml} / \mathrm{l})$} & \multirow{2}{*}{ Average } \\
\hline & & $\mathrm{k}_{0}$ (control) & $\mathrm{k}_{1}(2,5 \mathrm{ml} / \mathrm{l})$ & $\mathrm{k}_{2}(5,0 \mathrm{ml} / \mathrm{l})$ & $\mathrm{k}_{3}(7,5 \mathrm{ml} / \mathrm{l})$ & \\
\hline \multirow{3}{*}{2 WAP } & $\mathrm{v}_{1}=$ Maserati & 2.53 & 2.47 & 2.53 & 2.40 & $2.48 \mathrm{a}$ \\
\hline & $\mathrm{V}_{2}=$ Lokananta & 2.67 & 2.53 & 2.80 & 2.47 & $2.62 \mathrm{ab}$ \\
\hline & $v_{3}=$ Sanren & 2.67 & 2.80 & 2.93 & 2.67 & $2.77 \mathrm{~b}$ \\
\hline \multirow{4}{*}{3 WAP } & Average & 2.62 & 2.60 & 2.76 & 2.51 & \\
\hline & $v_{1}=$ Maserati & 4.33 & 4.60 & 5.00 & 4.47 & $4.60 \mathrm{a}$ \\
\hline & $\mathrm{V}_{2}=$ Lokananta & 4.87 & 5.07 & 5.13 & 4.67 & $4.93 \mathrm{a}$ \\
\hline & $\mathrm{v}_{3}=$ Sanren & 4.93 & 5.27 & 6.53 & 5.60 & $5.58 \mathrm{~b}$ \\
\hline \multirow{4}{*}{4 WAP } & Average & 4.71 & 4.98 & 5.56 & 4.91 & \\
\hline & $v_{1}=$ Maserati & 6.67 & 6.00 & 7.47 & 6.60 & $6.68 \mathrm{a}$ \\
\hline & $\mathrm{V}_{2}=$ Lokananta & 5.80 & 6.93 & 7.87 & 6.27 & $6.72 \mathrm{a}$ \\
\hline & $v_{3}=$ Sanren & 8.60 & 9.13 & 10.47 & 8.33 & $9.13 \mathrm{~b}$ \\
\hline \multirow{5}{*}{5 WAP } & Average & $7.02 \mathrm{a}$ & $7.36 \mathrm{a}$ & $8.60 \mathrm{~b}$ & $7.07 \mathrm{a}$ & \\
\hline & $v_{1}=$ Maserati & 7.13 & 8.00 & 8.87 & 7.93 & $7.98 \mathrm{a}$ \\
\hline & $\mathrm{v}_{2}=$ Lokananta & 6.93 & 8.07 & 10.20 & 8.20 & $8.35 \mathrm{a}$ \\
\hline & $v_{3}=$ Sanren & 9.60 & 12.20 & 16.47 & 12.93 & $12.80 \mathrm{~b}$ \\
\hline & Average & $7.89 \mathrm{a}$ & $9.42 \mathrm{a}$ & $11.84 \mathrm{~b}$ & $9.67 \mathrm{a}$ & \\
\hline
\end{tabular}

Note: The numbers followed by the same lowercase letters in rows and columns showed no significant difference in the DMRT test at the $5 \%$ level.

The number of leaves parameter with a concentration level of $5.0 \mathrm{ml} / \mathrm{l}(\mathrm{k} 2)$ gave the highest response when compared to other concentration level treatments. this is assumed to be a concentration of $5.0 \mathrm{ml} / \mathrm{l}(\mathrm{k} 2)$, was the optimal amount for plants to absorb nutrients, this is in accordance with Yulyatin's opinion et al. (2019) that Proper fertilization is one that affects the production of wrong shallots. Fertilization with high doses may not necessarily increase crop yields, especially if it is carried out in areas that have been used for intensive cultivation.

Similar to plant height, the number of leaves increased with increasing concentration of fertilizer applied to a concentration of $5.0 \mathrm{ml} / \mathrm{l}(\mathrm{k} 2)$, then it will decrease as concentration is increased. It was in accordance with Deshi's opinion et al. (2018) that at the beginning of plant growth the number of leaves increased rapidly and then stabilized after reaching a certain time in growth as a sign that the plant had experienced a slowdown in its growth and entered the generative phase.

The number of leaves parameter in the application of nanotechnology fertilizer application had a higher average number of leaves compared to control plants. It was in accordance with the opinion of Mujahidet al.(2017) that in the treatment given the application of nanotech fertilizers, the average number of leaves was higher than plants that were not given nanotech fertilizers. It is suspected because nanotech compound fertilizers contain complete nutrients needed by plants, according to Diamond Interest International (2019) that nanotech fertilizers (DIGrow) contain a variety of complete natural nutrients, namely: 16 macro minerals and micro minerals, 17 essential amino acids (asparic acid), glutamic acid, serine, glycine, histidine, arginine, threonine, alanine, proline, tyrosine, valine, methionine, cystine, isoleucine, leucine, phenylallanine, lysine), hormone/growth regulator (gibberellin, auxin, cytokinin), astringent soil (humic acid, alginic acid and fulvic acid).

The results of the ANOVA number of tubers per clump on the treatment of three varieties of shallots showed very significant results, the treatment of the concentration level of fertilizer showed significantly different results and the treatment of the concentration level of fertilizer and the three varieties both had no significant effect on the interaction. Observational data can be seen in Table 3. 
Table 3 - The average number of tubers per clump (tuber) of three varieties of shallot from seed (TSS) on differences in the concentration of nanotech compound fertilizers

\begin{tabular}{|c|c|c|c|c|c|}
\hline \multirow{2}{*}{ Varieties } & \multicolumn{4}{|c|}{ Fertilizer Concentration $(\mathrm{ml} / \mathrm{l})$} & \multirow{2}{*}{ Average } \\
\hline & k0 (control) & $\mathrm{k} 1(2,5 \mathrm{ml} / \mathrm{l})$ & $\mathrm{k} 2(5,0 \mathrm{ml} / \mathrm{l})$ & k3 $(7,5 \mathrm{ml} / \mathrm{l})$ & \\
\hline $\mathrm{v} 1$ = Maserati & 1.00 & 1.07 & 1.25 & 1.00 & $1.08 \mathrm{a}$ \\
\hline v2 = Lokananta & 1.40 & 1.42 & 1.92 & 1.42 & $1.54 \mathrm{~b}$ \\
\hline v3 = Sanren & 1.67 & 2.04 & 2.47 & 2.08 & $2.07 \mathrm{c}$ \\
\hline Average & $1.36 \mathrm{a}$ & $1.51 \mathrm{a}$ & $1.88 \mathrm{~b}$ & $1.50 \mathrm{a}$ & \\
\hline
\end{tabular}

Note: The numbers followed by the same lowercase letters in rows and columns showed no significant difference in the DMRT test at the $5 \%$ level.

Table 3 showed that the treatment of the three varieties had a very significant effect on the number of tubers per clump with the response of the treatment of the Sanren variety (v3) shows the highest average. The relationship between the number of tubers and the number of leaves is positively correlated, this shows that the more leaves per clump, the more tubers per clump, this is in accordance with Saidah's opinion.et al.(2019) that the red onion of the Sanren variety has taller plants and more leaves. It was in accordance with the description of the red onion of the Sanren variety, which has taller plants and more leaves than the Lokananta variety. This optimal vegetative growth allows the number of tillers to form more so that the number of tubers is also greater. The picture above shows that the Sanren variety has adaptability better than Lokananta and Maserati varieties. Each shallot variety has superior characteristics, superior varieties with special properties such as resistance to certain pests and diseases, plant characteristics (leaf shape, leaf color, tuber shape, and bulb color), as well as plant growth and productivity and able to live off-season. planting so that the sustainability of shallot production can be guaranteed (Suwandi, 2014).

The average number of tubers in the Sanren variety with an average of 2.07 bulbs/clump is the minimum number of the Sanren variety description, (East West Seed Indonesia, 2013) states that the Sanren variety has a plant height $54.03 \mathrm{~cm}-56.50 \mathrm{~cm}$ with 24 bulbs per clump. The number of tubers has something to do with the size of the tubers, where varieties with large tubers tend to have fewer tubers. This is in accordance with the opinion of Manohar et al. (2017) that these differences are caused by differences in genetic variations that interact with growth conditions, climate, maturity and harvest season.

Shallots of the Sanren variety have taller plants, more leaves and are positively correlated with the number of tubers produced. This is in accordance with the description of the Sanren variety of shallots, which have taller plants and more leaves than other varieties of shallots. This optimal vegetative growth allows a large number of tillers. This is in accordance with Saidah's opinion et al. (2019) Optimal vegetative growth allows a greater number of tillers to be formed so that the number of tubers is also greater.

The treatment of different concentrations of compound fertilizers with nanotechnology significantly affected the number of tubers per clump, with a concentration treatment response of $5.0 \mathrm{ml} / \mathrm{l}(\mathrm{k} 2)$ shows the highest average number of tubers, it is suspected that the application of fertilizer with a concentration of $5.0 \mathrm{ml} / \mathrm{l}$ is the optimal amount for plants to absorb nutrients, the response to the nanotech compound fertilizer treatment shows a high average number of tubers compared to the control. It is suspected that the $\mathrm{K}$ content in compound fertilizers with nanotechnology can increase plant metabolism, this is in line with Alfian's research et al. (2015) stated that the potassium element contained in organic fertilizers can increase enzyme activity in photosynthesis and respiration reactions so as to increase the number of tubers per clump, tuber diameter and tuber fresh weight. This is in accordance with the opinion of Hawanti and Andika (2018) that the use of organic fertilizers is the right way not only to produce crop productivity but also to maintain the stability of plant production intensively.

The results of the ANOVA test on wet bulb weight per clump on the three varieties of shallots showed very significant differences, the fertilizer concentration level treatment showed significantly different results and the interaction of the two had no significant effect. Observational data can be seen in In table 4 it can be seen that the treatment of the three 
varieties had a significant effect on the parameters of wet tuber weight per clump, with the response to treatment of the Sanren variety ( $v 1)$ produced the highest average wet tuber weight, which was $40.84 \mathrm{~g}$ per clump. It is suspected that the Sanren variety is a variety that can adapt to the environment where the study is located, this is in accordance with Saidah's opinionet al.(2019) that plant growth and yield are manifestations of the influence of genetic and environmental factors. Each plant genotype can have a characteristic response to different environmental conditions.

Some of the agronomic characters in the form of growth components and plant yield components are more dominated by genetic factors, and some are more determined by differences in environmental factors. This is confirmed by the opinion of Suwandi (2014) that the productivity of shallots does not only depend on the varieties planted, but is also influenced by soil conditions and the environment in which they are grown.

Table 4 - Average wet tuber weight per clump (gi) of three varieties of shallot from seed (TSS) on differences in concentration of compound fertilizer with nanotechnology

\begin{tabular}{|c|c|c|c|c|c|}
\hline \multirow{2}{*}{ Varieties } & \multicolumn{4}{|c|}{ Fertilizer Concentration (ml/l) } & \multirow{2}{*}{ Average } \\
\hline & k0 (control) & $\mathrm{k} 1(2,5 \mathrm{ml} / \mathrm{l})$ & $\mathrm{k} 2(5,0 \mathrm{ml} / \mathrm{l})$ & k3 $(7,5 \mathrm{ml} / \mathrm{l})$ & \\
\hline $\mathrm{v} 1=$ Maserati & 24.25 & 29.77 & 33.18 & 30.92 & $29.53 \mathrm{a}$ \\
\hline v2 = Lokananta & 24.70 & 31.26 & 34.21 & 35.98 & $31.54 \mathrm{a}$ \\
\hline v3 = Sanren & 31.38 & 40.07 & 50.45 & 41.44 & $40.84 \mathrm{~b}$ \\
\hline Average & $26.78 \mathrm{a}$ & $33.70 \mathrm{~b}$ & $39.28 \mathrm{~b}$ & $36.11 \mathrm{~b}$ & \\
\hline
\end{tabular}

Note: The numbers followed by the same lowercase letters in rows and columns showed no significant difference in the DMRT test at the 5\% level.

In this study, the Sanren variety tended to produce higher wet bulb weight per clump of shallots than the Lokananta and Maserati varieties, even though these three varieties both had high yield potential. This is in line with the opinion of Purbiati, et al., (2010) that plant growth and growth are strongly influenced by external and internal factors. One of the factors is the genetic nature of the variety, while external factors are climate, temperature, humidity, rainfall, nutrient availability and sunlight intensity. The internal factor referred to above is the genetic factor of the Maserati variety itself, the Maserati variety has a smaller tuber weight compared to other varieties so that it affects the production of the plant Spodoptera exigua.

Based on Table 4, it shows that the concentration level treatment of nanotech compound fertilizer significantly affects the parameters of fresh tuber weight per clump, with a concentration level treatment response of $5.0 \mathrm{ml} / \mathrm{l}(\mathrm{k} 2)$ showed the highest average weight of fresh tubers per clump, which was $39.28 \mathrm{~g} / \mathrm{clump}$, the concentration level of nanotech fertilizer was up to $5.0 \mathrm{ml} / \mathrm{l}(\mathrm{k} 2)$ can increase the tuber weight, however, if the concentration is increased to more than $5.0 \mathrm{ml} / \mathrm{l}$, the tuber weight will decrease. This is presumably because the application of fertilizer concentrations that are too high can suppress plant growth. This is in accordance with Nuryani's opinion et al. (2019). Fertilizer application must be done correctly and according to the recommended concentration, because excessive fertilizer application will cause poisoning in plants. If the fertilization process is not appropriate and in accordance with the concentration, the results obtained are not optimal.

\section{CONCLUSION}

Application of nanotechnology multiple fertilizer with a concentration of $5.0 \mathrm{ml} / \mathrm{l}$ gave the best response (growth and yield) on plant height parameters 3 WAP $(25.39 \mathrm{~cm})$, number of leaves 4 WAP $(8.60 \mathrm{~cm})$ and 5 WAP (11.84 strands), number of tubers (1.88 bulbs), and wet tuber weight per clump (39.28 g). The Sanren variety gave the best performance (growth and yield) on plant height parameters at 2 WAP $(20.77 \mathrm{~cm}), 3$ WAP $(26.07 \mathrm{~cm}), 4$ WAP $(32.18 \mathrm{~cm})$, and 5 WAP $(41.12 \mathrm{~cm})$, the number of leaves 2 WAP $(2.77$ strands), 3 WAP (5.58 strands), 4 WAP (9.13 strands) and 5 WAP (12.80 strands), number of bulbs (2.07 bulbs), and weight wet tubers per clump (40.84 g). There was no interaction between the 
application of different concentrations of nanotech compound fertilizers and the use of different varieties to all observed parameters.

\section{REFERENCES}

1. Alfian F. D, Nelvia, Yetti H. 2015. Effect of Potassium Fertilizer and Compost Mixed Empty Palm Oil Bunches with Boiler Ash on the Growth and Yield of Shallots (Allium ascalonicum L.). Faculty of Agriculture, University of Riau.

2. Ariningsih, E. 2016. Prospects of Application of Naon Technology in Agriculture and Food Processing in Indonesia. Journal of the Agro-Economic Research Forum. Vol. 934(1):120.

3. Agricultural Research and Development Agency (Balitbang Pertanian). 2015. Indonesian Agricultural Land Resources. Widespread, and Potential Availability. IAARD Press. 100 pages.

4. Central Bureau of Statistics (BPS). 2019. Expenditure for Population consumption Indonesia by Province (results based on the September 2019 Susenas).

5. Central Bureau of Statistics (BPS). 2020. Horticulture Statistics Year 2019. Vegetable Crops Research Institute (Balitsa). 2015. TSS Cheap Way of Planting Red onion. http://balitsa.litbang.pertanian.go.id/. Retrieved October 16, 2020.

6. Center for Research and Development of Agricultural Land Resources (BBSDLP). 2020. Dry Land Technology Increases Production. https:// bbsdlp.litbang.pertanian.go.id/. Retrieved 17 May 2021.

7. Deshi K, Obasi M, Nanbol K. Sirajo S. Okechalu B. 2018. The Effect of Growth Environments on the Growth and Yield of Bawang Bombay (Allium Cepa L.) in Jos, Plateau State, Nigeria. J Nat Sci Res. 8(6): 67-74.

8. Diamond Interest International. 2019. Description of Technological Compound Fertilizer Nano (DIGROW). Jakarta.

9. Directorate General of Horticulture (Directorate General of Horticulture). 2018. Technical Instructions Vegetable and Medicinal Plant Development Activities in 2019. Directorate General of Horticulture, Ministry of Agriculture. Jakarta.

10. Fageria, NK and VC Ballgar, 2005. Enchancing Nitrogen Use Efficiency in Crop Plants. J. Advances in Agronomy 8(8): 97-185.

11. Hawaanti, Erni and Andika, Rahmad. 2018. the effect of the type of organic fertilizer on the growth and production of several varieties of shallot (Allium ascalonicum I.) in rainfed land. chlorophyll XIII - 1: $42-49$, June 2018.

12. Jamilah and Novia, E. 2016. Effect of Crocober Liquid Organic Fertilizer on Onion Plant (Allium ascalonicum L.). Journal of Applied Science and Technology. Vol. 8(2): 67-73.

13. Jumini, Marliah A, Fahmi R. 2011. Responses of Several Shallot Varieties Due to Differences in Planting Distances in the Intercropping System on Ex-Tsunami Lands. J. Floratek 6: $55-61$.

14. Ministry of Agriculture (Kementan). 2020. Annual Report of the Directorate General Horticulture in 2018. Directorate General of Horticulture, Ministry of Agriculture. Jakarta.

15. Kushlaf N, Rashed A, Mohamed KS, Mahmoudy AME, Almunir N, Elshili MM, Oshkondali STM. 2019. Effect of organic fertilizers and complete chemical fertilizers (nitrogen, phosphorus, potassium) on green onions growth and yield. South Asian Res J Agri Fish. 1(3): 73-77.

16. Manohar CM, Xue J, Murayyan A, Neethiraajan, Shi J. 2017. Antioxidant activity of polyphenols from Ontario grown onion varieties using pressurized low polarity water technology. Func.Foods.(31): 52-62.

17. Mehran, Kesumawati E, Sufardi. 2016. Growth and yield of some varieties Red onion (Allium ascalonicum $L$ ) on alluvial soil due to the application of various doses of NPK fertilizer. J. Floratek 11(2):117133.

18. Mujahid A., Sudiarsono, Aini N. 2017. Application Test of Nanotechnology Fertilizers on Shallot Cultivation (Alternanthera amoena Voss.). J. Crop Production. Vol. 5 No. 3, March 2017:538-545. 
19. Nur'aeni, E. 2020. The Effect of Giving Several Concentrations of Compound Fertilizer Nanotechnology on Growth and Yield of Three Shallot Plant Varieties (allium ascalonicum I.) (Thesis). Attack. Sultan Ageng Tirtayasa University.

20. Nurjanani and Djufry F. 2018. Test the Potential of Several Shallot Varieties to Produce Botanical Seeds in the Highlands of South Sulawesi. J. Hort. 28 (2):1-8

21. Nuryani E, Haryono G, Historiawati. 2019. Effect of dose and time of administration fertilizer $p$ on the yield of chickpeas (Phaseolus vulgaris, L.) upright type. VIGOR: 4(1): 14 $-17$.

22. Pangestuti, R and Sulistyaningsih, E. 2011. Potential uses True Seed shallot (TSS) as a source of shallot seeds in Indonesia. Proceedings of the National Seminar on "Agri Innovation Support for Farmer Empowerment in Agribusiness Development for Rural Communities". Semarang. July 14, 2011.

23. Pikukuh P, Djajadi, Tyasmoro SY, Aini N. 2015. Effect of Frequency and Concentration of Spraying Nano Silica (Si) Fertilizer on Sugar Cane Plant Growth (Saccharum officinarum I.). Journal of Crop Production, Vol. 3 No. 3, Pg. 249-258.

24. Purbiati, T. Abdullah U. and Arry S. 2010. Assessment of Adaptation of Onion Varieties Red is Tolerant to Pests and Diseases on Dry Land in West Kalimantan (Assessment of Adaptation of Shallots Varieties Pest Tolerant Disease on Dry Land in West Kalimantan). http://kalbar.litbang.pertanian.go.id/

25. Putri F. 2021. Characteristics of Bioactive Ingredients, Leaf Growth and Production Shallots at Different Altitudes, Seasons and Fertilizer Doses (Dissertation). IPB.

26. Saidah, Muchtar, Syafrudin and Pangestuti R. 2019. Growth and yields two varieties of shallots from seeds in Sigi Regency, Central Sulawesi. PROS SEM NAS MASY BIODIV INDON 5 (1): 213-216, March 2019.

27. Selvi, DT, and Saraswathy, S. (2017). Seed viability, seed deterioration and seed quality improvements in stored onion seeds: a review. Journal of Horticultural Science and Biotechnology, 93(1), 1-7, DOI:10.1080/14620316.2017.1343103.

28. Simatupang, S. 2019. Study of the Number of Populations and Varieties of Production and Benefits of Shallot Farming in North Sumatra. J. Hort. Vol. 29 No. 2, December 2019: 219-230.

29. Sudaryono, T. 2017. Influence of Modification of Growth Medium and Using of Plantgrowth Regulator to Enhance Growing Power and Growth of True Seed of Shallot (TSS). Biotics 6(19): 2410-9290

30. Sumarni N, Rosliani R, Basuki RS. 2012. Growth response, tuber yield and NPK nutrient uptake of shallots against various doses of NPK fertilization on alluvial soil. J Hort 22(4): 366-375.

31. Suwandi. 2014. Off-Season Shallot Cultivation. Research Agency and Agricultural Development Ministry of Agriculture. IAARD Press, Jakarta.

32. Tabor, G. 2018. Development of Shallot varieties seeds (Allium Cepa L var. aggregate) in Ethiopia. Scientia Horticulturae 240 89-93. https:// www.sciencedirect.com/. Retrieved 04 November 2020.

33. Tarigan, Liri Sari (2019) Effect of Rice Straw Mulch Thickness on Growth and Yield of 2 Shallot Varieties (Allium Ascalonicum L.) On Dry Land. Bachelor's thesis, Universitas Brawijaya.

34. Wati, Tika Anisa Padar and Sobir. 2018. Demonstration of Seven Varieties of Shallots (Allium Cepa L. Aggregatum group) TSS (True Shallot Seed). Horticulture Journal 2(3):16-24.

35. Wulandari, A, Purnomo, D \& Supriyono 2014. Potential of Onion Botanical Seeds (True Shallot Seed) as Planting Material for Shallot Cultivation in Indonesia, EL VIVO, vol. 2, no. 1, p. 28-36.

36. Yanuar, F and Widawati, M. 2014. Utilization of Nanotechnology in Development of Organic Fertilizers and Pesticides. Journal of Health Research and Development. No 21.

37. Yulyatin A, Dianawati M, Haryati W. 2019. A review of technology packages fertilizing shallots with mini tuber seeds in Cirebon Regency. JPPTP. 22(3): 355-362. 